\title{
Book Review: Reason in a Dark Time: Why the Struggle Against Climate Change Failed and What It Means for Our Future
}

\author{
Edmond Sanganyado* \\ Marine Biology Institute, Shantou University, Shantou, China
}

Keywords: environmental ethics, climate change adaptation, climate change mitigation, environmental policy development, book review, climate science

\section{A Book Review on}

Reason in a Dark Time: Why the Struggle Against Climate Change Failed and What It Means for Our Future

Dale Jamieson (Oxford: Oxford University Press), 2017, 288 pages, ISBN: 978-0190845889

\section{OPEN ACCESS}

Edited and reviewed by: Karen L. Bacon,

University of Leeds, United Kingdom

${ }^{*}$ Correspondence:

Edmond Sanganyado esang001@ucr.edu

Specialty section:

This article was submitted to Quaternary Science, Geomorphology and Paleoenvironment, a section of the journal Frontiers in Earth Science

Received: 10 October 2017 Accepted: 02 March 2018 Published: 20 March 2018

Citation:

Sanganyado E (2018) Book Review: Reason in a Dark Time: Why the Struggle Against Climate Change Failed and What It Means for Our Future. Front. Earth Sci. 6:23. doi: 10.3389/feart.2018.00023
What would you do if you discover the things you are doing will cause a global catastrophe? You will probably attempt to alleviate the disaster by desisting from the perilous actions and you would invest in efforts that could undo any present damage. However, if you think the problem is too big, and would primarily affect people in another continent after 100 years, would you continue with the mitigation efforts? Climate change policies have failed, writes philosopher Dale Jamieson after pondering these questions: Human perceptions, he argues, of moral and economic responsibility are evolutionarily limited in comprehending events outside one's own space and time. Thus, in his clear, concise and engaging book, Reason in a Dark Time, Jamieson skillfully shows climate change is "a perfect moral storm" (Gardiner, 2011) and an elusive economic hurricane.

In his previous books, Jamieson explored the intersection between morality and environmental problems such as pollution, reduction in biodiversity, climate change and land degradation (Jamieson, 2004, 2008). In Reason in a Dark Time, Jamieson offers a captivating autopsy of the failed climate change policies. He chronicles the history of climate science (chapter 1 and 2), and discusses the challenges faced by scientist, policymakers and the public in translating scientific data into behavioral change (chapter 3), the inadequacy of economics (chapter 4) and the potential of environmental ethics to address environmental problems (chapter 5 and 6), and finally, recommendations for policymakers on incorporating environmental ethics in climate change adaptation (chapter 7 ).

Jamieson proposed climate scientist should actively promote scientific curiosity by engaging the public and policymakers on matters concerning climate change adaptation. A comprehensive understanding of the magnitude of the climate change problems should acknowledge the weaknesses of human beings to comprehend problems that are multidimensional and multigenerational. Such problems are better understood in scientific discourse. Hence, adaptation and mitigation proposals meet resistance and suspicion due to the absence of common language. A poor understanding of the scientific process, lack of confidence in science and rampant politicization of science encourage "scientific ignorance." Furthermore, "scientific ignorance" is sometimes perpetuated by scientists who fail to translate scientific data into nontechnical language for policy formulation, and policymakers who lack a basic understanding of science. 
Often, environmental ethicists view climate change as morality question with a known perpetrator predicted consequences and an abstract victim. Since the victims are not in the same space and time as the perpetrator, culpability is often difficult to perceive. Furthermore, nations affected by climate change the most are often least responsible for the emission of greenhouse gases and carbon dioxide known to contribute to climate change. For example, Southern Africa contributes less than one-twelfth of greenhouse gas and carbon dioxide emissions, yet it is one of the most vulnerable regions. Thus, proposals made by nations in Southern Africa should be prioritized. However, suggestions and demands made by developed nations, which contribute more than $80 \%$ of greenhouse gases and carbon dioxide, are prioritized. For example, the US often used its financial muscle to hold at ransom climate the Kyoto Protocol, Copenhagen Accord and recently the Paris Agreement. Importantly, developed nations often view climate change as an economic problem. Jamieson argued, "Economics has much to say about incentives and costs, but little or nothing to say about 'optimal' policies."

Climate economist may question the rebuttal of global benefitcost analysis as a tool for climate change policy formulation, as well as Jamieson's suggestion that economic models promote self-interests rather than addressing global challenges. Readers inclined to philosophy will be troubled by his insistence that his proposed green virtues are different from Christian ethics, even though he did not offer a substantive discussion on the

\section{REFERENCES}

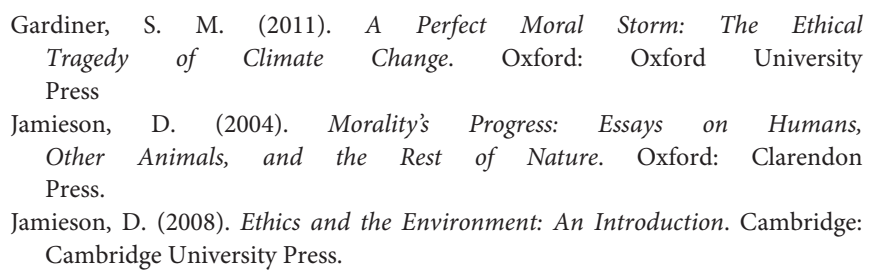

Jamieson, D. (2008). Ethics and the Environment: An Introduction. Cambridge: Cambridge University Press.

supposed differences. However, with an inadequate discussion on how evolution limit human comprehension of complex problems like climate change, it is hard to appreciate the impact Jamieson's Anthropocene ethics-finding meaning in relationships with other humans, animals, nature and the world-on climate change adaptation. A discussion on how humans adapted or developed resilience to environmental change, contrasted to the proposed Anthropocene ethics would have been helpful.

The roots of failure to implement or formulate effective climate change policies can be traced to inadequacy of economics and ethics to frame perceive risk in multidimensional and multigenerational problems. Jamieson acknowledged this problem and proposed the adoption of "green virtues" as a mechanism for climate change adaption. Reason in a Dark Time is timely since it confronts climate change denialism which is currently rising in Western countries, particularly in the US. Although Jamieson's recommendations are not novel and susceptible to the obstacles he clearly narrated in the book, climate scientist, policymakers and the general public will find the book useful as it encourages a paradigm shift in science, economics and ethics.

\section{AUTHOR CONTRIBUTIONS}

ES read Dale Jamieson's Reason in a Dark Time and prepared the book review.
Conflict of Interest Statement: The author declares that the research was conducted in the absence of any commercial or financial relationships that could be construed as a potential conflict of interest.

Copyright (C) 2018 Sanganyado. This is an open-access article distributed under the terms of the Creative Commons Attribution License (CC BY). The use, distribution or reproduction in other forums is permitted, provided the original author(s) and the copyright owner are credited and that the original publication in this journal is cited, in accordance with accepted academic practice. No use, distribution or reproduction is permitted which does not comply with these terms. 